highest percentage (39.9 per cent) of the 102,830 victims of road traffic accidents who needed hospital treatment. Fractures of different parts of the body made up most of the rest of the total; burns, however, accounted for only $0 \cdot 1$ per cent of road traffic injuries. Poisons caused a high proportion of accidents in the home 33.1 per cent out of the estimated total of 133,490 home accidents noted in the enquiry. Figures are given for all kinds of poisons-even strychnine and belladonna are included in the results.

\section{Agreement Signed}

A TEOHNOLOGICAL agreement between the United Kingdom and the USSR which has been talked of for some time was signed last week by the technology chiefs of the two countries (see Nature, 216, 1060; 1967). The Russian delegation, which spent four days in London completing negotiations with the Ministry of Technology, was led by Academician V. A. Kirillin, Deputy Chairman of the Council of Ministers and Chairman of the State Committee of the Council of Ministers of the USSR for Science and Technology. Mr Anthony Wedgwood Benn, the minister, and Mr Fred Mulley, Minister of State at the Foreign Office, signed on behalf of the British Government. The agreement provides for investigation of topics of mutual interest to the two countries at all levels, and is seen as the beginning of a "special industrial relationship". Mr Wedgwood Benn hopes that each side will "discover what is interesting, and pursue it".

The ministers, or their deputies, will meet once w year to reviow the working of the agreement, with reference to the progress of scientific, technologicel and economic co-operation. Joint working parties will determine the fields for cooperation and will recommend specific subjects for investigation in the fields of research, development, technology and organization of industry. Contacts at all levels will be encouraged as a means of turning the agreement into action. Exchange visits for studies, training and consultation will be arranged. Facilitics will be provided for research and practical experience in each country and scientific and technical information will be exchanged. It is expected that licensing arrangements will be made to suit circumstances as they arise. The agreement places no limit on the joint work that can be done, as it provides for "any form of co-operation in applied science and technology as may be mutually agreed".

Five subjects which have been agreed, and are to be investigated by working groups, are educational technology, transport technology, materials research, information storage, processing and retrieval and non-conventional methods of food production. The ten items under the heading of industrial technology include the topics already being investigated by the Confederation of British Industry following the visit of a delegation to Russia last autumn.

\section{Viking Ships on the Move}

\section{from Angela Croome}

Srx years ago the Danish National Museum recovered the timbers of five 1,000-year-old Viking ships from Roskilde Fjord in an intensive and precisely calculated 3-month exercise which followed several years of underwater investigation. The ships, dated by carbon14 measurements of caulking material, were known to be expendable hulks stripped down to essentials and sunk with stones across the main navigation channel to block access to the rich settlement at the head of the fjord which later became the medieval Danish capital of Roskilde. The fjord was shallow, so that a low cofferdam was enough to enable pumping out and salvage of the timbers (see picture).

By now the first ship has completed the long and tricky "pickling" process needed to preserve its fragile timbers in air, and the work of turning these back into a ship can begin. This will take place in a specially built ship museum on the banks of the Roskilde Fjord where the first ship to complete processing is to move this week. Museum staff expect reassembly of the first ship to be completed this year when the new museum will be: opening to the public. After that, visitors can watch the other ships assembled one by one. The ship being moved to the museum this week is made up of 5,000 individual pieces of wood. These have taken from 6 months to 2 ycars to be "rehabilitated"- - the waterfilled gaps must be filled with ethyl-glycol so that the wood, saturated for a thousand years in water, will not shrink when exposed to air. A cycling process in solution tanks heated to $60^{\circ} \mathrm{C}$ has been employed and has taken longer than originally expected. It may yet be: a vear or so before the remaining ships are ready for

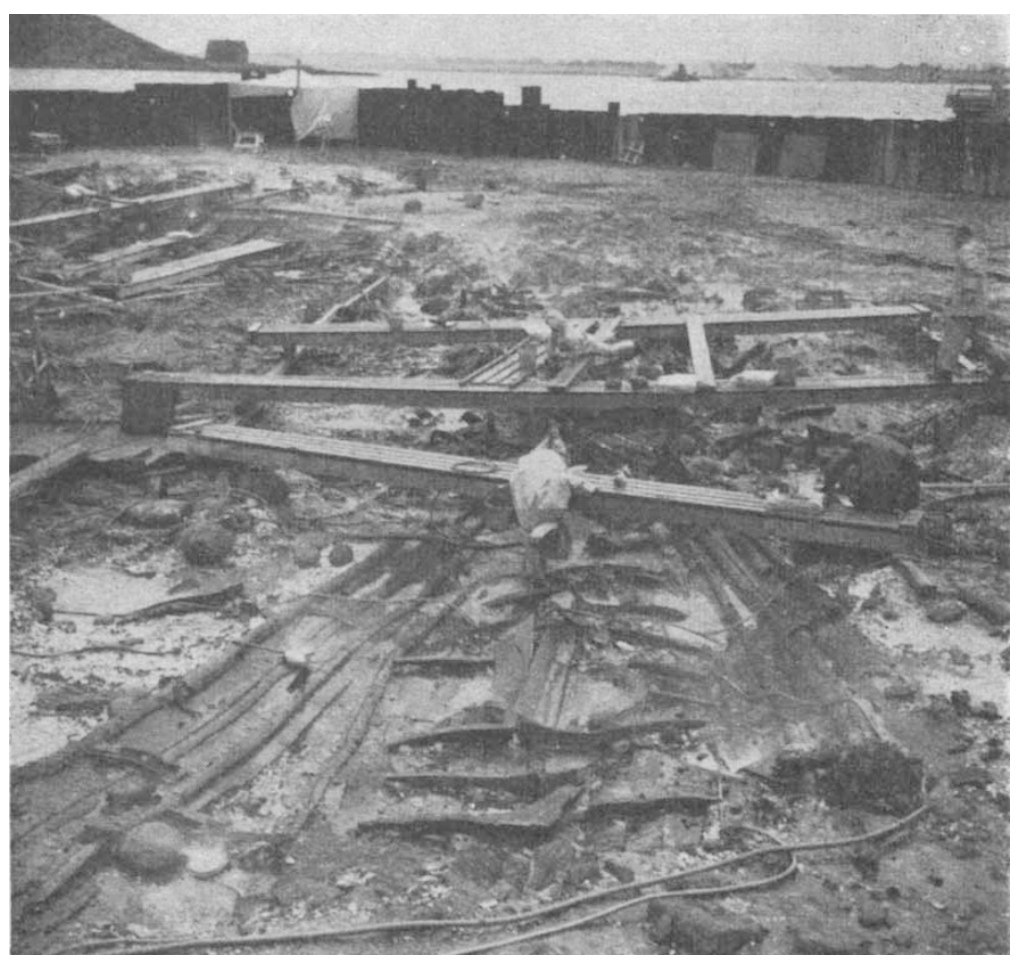

The skeleton of one of the five tenth-century Viking ships emerges from the mud of Roskilde Fjord. When this picture was taken, in August 1962, the work of clearing the ships of mud and stones was two-thirds complete. Garden sprinklers are in use to keep the exposed wood damp. 
reassembly. Each timber must conform to the original tracing in horizontal shape and size before reconstruction can begin. The third dimension can be produced by heating but not the stretching of basic length and breadth.

Each of the five ships is different. The one being moved for reassembly this week is a 40 - $\mathrm{ft}$. ocean-going cargo vessel such as was used by Erik the Red and his successors for the early Norse voyages to Greenland and North America- - "Vinland" as the sagas called it. This is a stout, decked sailing ship of pine on an oak frame with a heightened freeboard. Another is a classical "Iongship" such as chieftains used on coastal forays, $90 \mathrm{ft}$. long and built of oak. Another is the coastal assault craft which is well illustrated in the Bayeux tapestry of the Norman Conquest of England (the Normans were descended from the Norsemen). The best preserved of the Roskilde Viking ships is an oak ship thought to have been used for coastal freighting in the Baltic. And there is a smaller boat which remains something of a mystery-nothing similar has been found in the records. It may have been used for netfishing. It has neither deck nor oar-holes and is built of pine which at that period was unknown in Denmark. This suggests that it may have originated in southern Norway.

Mr Ole Crumlin-Pedersen, the naval architect who has been responsible for the finds, plans to build a fullsize replica of the Atlantic craft with identical materials and a set of Viking shipwright's tools, to see how she handles at sea. He has already done this for the assault craft shown on the Bayeux tapestry and found it quite easy to load and land horses from the foreshore as shown in the tapestry.

\section{Pattern of Research}

\section{from Our Special Correspondent}

The MRC Metabolic Reactions Research Unit in the Biochemistry Department at Imperial College, London, under Professor E. B. Chain, shows a common pattern of research, as a public visit on Tuesday of this week illustrated. The pattern has four components: a belief that biochemistry done on complete organs or tissues is likely to yield results nearer to the reality of living animals than can be got from enzyme preparations; exceptional resources for making and processing analyses and counts of radioactive tracers in a multiplicity of materials; the facilities for pilotscale fermentation on which Professor Chain insisted from the start; and the personal dominance which he still exercises. The unit has a scientifically qualified staff of 15 including attached workers and the department some 20. Interesting and potentially promising use of congenital obesity in mice is being made by Dr C. Chlouverakis. His most recent experiment shows a difference in response to insulin between diaphragm muscle and adipose tissue in these mice, and also an age effect. Muscle does not respond to insulin; adipose tissue in five month old animals does. By the age of a year the second response has disappeared and at the same time the weight of the animals levels out. Recent medical evidence on maturity-onset diabetes and obesity suggests that Dr Chlouverakis's research may bo relevant to man. He plans next to look for biochemical differences associated with the tissue and age effects. Mr K. R. L. Mansford and others are working on the metabolism of complete hearts. They are interested in the partial revival of activity which follows the initial severe drop induced by oxygen deficiency. Dr H. F. Bradford, Mr K. Corbett and Dr S. P. R. Rose have gone some way towards establishing that the brain of the snail, which has cells at least ten times larger than the human brain, can be used as a simplified model from which a biochemical picture of the working of brains, including the interrelation of neurones and glia, may be in time built up. Other research, at an early stage, follows the demonstration by $\operatorname{Dr} P$. Mantle in the department that agroclavin (closely related to the ergot alkaloids and in particular to LSD) has a central and specific inhibitory effect on lactation. Because agroclavin is much less toxic than LSD, study of the mechanisms by which it produces central effects, some of which appear to be shared by LSD, may give some helpful leads on the latter. This research should be worth doing in any case because of the side effects of agroclavin that may be brought to light. There is also supporting development work on automated instrumentation and data processing applied to biochemical methods of analysis and separation. Because of the opportunities that the unit and department together provide, there will be a case (in better times) for more senior posts in the department.

\section{Applying to See Stars}

THE Science Research Council has set up a panel, chaired by the Astronomer Royal, to allocate time on the three large telescopes which it will eventually be supporting. These are the 74-inch reflector at Pretoria, leased from the Radcliffe Trustees for seven years from 1967, the 98-inch Isaac Newton telescope at Herstmonceux, now undergoing commissioning trials, and the projected Anglo-Australian 150-inch reflector at Siding Spring in New South Wales, half of the observing time on which will be available to United Kingdom astronomers. Observing time at the Radcliffe Observatory will be shared between the present staff, the Royal Greenwich and Cape Observatories and United Kingdom astronomers in general.

Astronomers based in the United Kingdom who wish to use the telescopes are asked to apply to the Secretary of the Panel, Dr A. Hunter, whose address is the Royal Greenwich Observatory, Herstmonceux Castle, Hailsham, Sussex. The panel's duty is to consider applications on their scientific merits and to allocate time to individual users in accordance with SRC policy. Applications to use the Radcliffe reflector should be made one year in advance, and to use the Isaac Newton telescope six months in advance.

The panel itself disposes only of time, not of money; applications for grant support should therefore be made in parallel to the Science Research Council.

\section{Cousin, not Cousine}

Cousin IsLand is a small island of 67 acres (not to be confused with a neighbouring island, Cousine) in the Seychelles, about 800 miles north-east of Aldabra Island, which is shortly to be bought and turned into a nature reserve. That, at least, is the hope. For seven years the International Council for Bird Preservation has been bargaining to buy the island and now a firm offer for the island has been accepted. With the 